\title{
Pre-Service Teachers' Perception of Online Learning in Islamic University during a Coronavirus (Covic-19) Pandemic
}

\author{
Nafan Tarihoran ${ }^{\mathrm{a}}$, Bayi Syafuri ${ }^{\mathrm{b}}$, Masykur ${ }^{\mathrm{c}}$ \\ ${ }^{a}$ Associate Professor in Education, UIN Sultan Maulana Hasanuddin Banten, Indonesia \\ ${ }^{\mathrm{b}}$ Professor in Islamic Studies, UIN Sultan Maulana Hasanuddin, Banten, Indonesia \\ ${ }^{c}$ Assistance Professor in Humanities, UIN Sultan Maulana Hasanuddin Banten, Indonesia \\ acCorresponding Author: Email: nafan.tarihoran@uinbanten.ac.id
}

Article History: Received: 10 November 2020; Revised 12 January 2021 Accepted: 27 January 2021; Published online: 5 April 2021

\begin{abstract}
The threat of Corona Virus (Covid-19) has presented unique challenges for the institution of higher education, and it hit most aspects of life, including the education sector. This study aimed to investigate the effectiveness of online learning during the COVID-19pandemic. Data collection in this study was 113 respondent active students participated in this study at the Faculty of Islamic Education and Teacher Training, the State Islamic University of Banten. The sample collection method used simple random sampling conducted online. This research was a quantitative study using a survey method. The study analysed the effect of gender, age, and years of online learning experience differences on students' perception of learning activities. This paper also explained about kinds of online learning used during the COVID-19 pandemic. It can be concluded that online learning was effective because the conditions that required online study and the lecturer-students talk as not as effective as in the normal classroom. The results of the study have implications for online lecturers, students, and administrators. Supports from institution and government are needed for the success of online learning.
\end{abstract}

Keywords: Covid-19, online learning, pandemic, pre-service teacher

\section{Introduction}

The pandemic COVID-19 is an emerging epidemic with significant effects on the education system. Most heads of academia now advocate online education as a response to this problem. Educational institutions face decisions about how to continue teaching - learning process while safeguarding their lecturers and students from a public health emergency that is moving rapidly and not well understood (UNESCO, 2020). Educational institutions Offer many online learning opportunities and full degree programme. Learning and teaching practices are changing, which have implication to the essence of learning experiences of students (Demuyakor, 2020).

The traditional teaching approach changed from lecturer to student into the student centre. This is meet the continuous increase in online learning enrolment. Many universities have decided to cancel all face-to - face classes and other learning opportunities and have forced universities to move their courses online to help prevent COVID-19 from spreading viruses (Murphy, 2020; Yulia, 2020). The list of higher education institutions taking this decision has expanded every day. Institutions of all sizes and forms — State universities and colleges, including Islamic universities in Indonesia are moving their classes online (Fithra, 2020; Simamora, 2020) Nadiem Makarim, Indonesia ministry of Education (MoNec) through decree no. 4 the year 2020 which contents about implementing education policies in the emergency phase of pandemic covid-19, boosted up the educator to teach from home(Djuanda et al., 2020). For many developing countries, online learning appears as a fundamental way of teaching and learning, thus making the ration of preservice teacher towards negative direction (Sharma, U., Forlin, C., Deppeler, J. \& Guang-xue, 2013).

The MoNec has also made considerable investments in the confidence to achieve the objective of advancing the standard of education by enhancing the learning environment with the help of educational technologies (Adit, 2020). As reported by the Minister of MoNEC, Nadiem Makarim debuted Merdeka Belajar or was free to learn that integrating technology training into all levels of education and providing access to technology equipment and ICTs for each Indonesian student liberalized higher education policy (The Jakarta Post, 2020).

The education system in the country of Indonesia is based on Islamic education and public education and allows the students to attend regular school classes. Using technology in teacher pre-service classroom would have a positive effect on teacher's future. The impact can be looked at in terms of teacher position, teaching method and teaching materials. Dudeney stated that It is becoming increasingly important to use technology in the classroom and it will become a regular part of EFL practice (Dudeney, G. and Hockly, 2008). 
In Indonesia, online learning offers students and lecturers challenges and opportunities. The Indonesian education system, like various sectors of society, is also uneven, particularly because of the coming COVID-19 pandemic. Online learning can be one of the answers for the Pre-service Teachers to do some assessments toward their teaching-learning process in arrange to reach the circumstance in which studentsmightget it and comprehend what they learn. The key to the effective utilization of technology in language teaching lies not only in software and equipment but also pre-Service Teachers as a designer and implementing effective teaching activities. Welldesigned materials will make learning more efficient, more effective and less difficult (Morrison et al., 2013).

Even there are several studies investigated the use of technology, (Mardiah, 2020; Martin \& Bolliger, 2018; Whisenand et al., 2006), but only a few researchers examined the pre-service teachers' view in utilizing the technology in a particularized way. Pre-service teachers should be better trained to teach with technology from the first day, when they join the field. Curricula in teacher education, along with the teacher educators' use of technology for teaching and learning will impact the use of technology through teacher protection in future practice.

There is a growing number in studying' perceptions of learning online. However, as earlier stated, there are few, if any, studies that have investigated attitude about the undergraduate perception of online learning in an Indonesian Islamic university. The author decided to revisit some the issue raised by (Alqurashi, 2019; Ituma, 2011). The author set out the specific issues to answer, include:

1) What constitutes pre-service teachers' perception (understanding, experiences, attitude) of online learning as a part of teacher preparation?

2) Do pre-service teachers perceive online learning (interaction) as effective learning?

3) To what kind of learning environment (Synchronous, Asynchronous, blended online) is the strongest and usage of online meeting tool most significant learning?

\section{Literature Review}

\section{Corona Virus (COVID-19)}

Coronavirus contains viruses which have a single strand of ribonucleic acid in their genome. Health experts are worried about coronavirus, which has infected/killed thousands of people (Yang et al., 2020). This disease is part of the pathogen family that causes severe acute respiratory syndrome (SARS) that another person can easily touch.

In December 2019, this virus originated in a Chinese town, Wuhan. The Chinese authority has issued a travel ban in and out of the affected Chinese cities to control the outbreak of the disease. The affected communities have criticized this lockdown as a wrong decision due to psychological consequences resulting from demanding access to medical assistance, supplies or materials (Abere, 2020)

It may spread from animal to human, or from person to person, or be contacted. As a result, Soumya Swaminathan, the Chief Scientist at W.H.O in Switzerland, has officially named the disease caused by this coronavirus as COVID-19 (that is, coronavirus disease 2019). This is to differentiate past or potential outbreaks of this disease from other coronaviruses. The researchers at South China Agricultural University Guangzhou, on February 7, 2020, indicated in a press conference that an animal species (pangolin) is the cause of the disease outbreak. This was due to the animal's genetic similarity with the individual infected. Pangolins are animals which are sometimes used in Chinese local medicine(Gross, 2020).

On 30 January 2020, W.H.O Director-General Tedros G. Adhanom declared the outbreak of this disease a global health emergency because it could be epidemic and devastating to countries with inadequate healthcare facilities, (He et al., 2020; W.H.O, 2020). The global health emergency declaration will gear experts up to probe the infection biology, develop drug/vaccine and weigh up the worst-case scenario. A study at Schenzhen in China showed that some infected persons with the virus were not exhibiting any symptoms of the disease. This makes this virus deadly as it can be contacted without knowing by someone carrying the disease without showing signs. Within a very short time of novel coronavirus emergence, many papers/articles had been written on it. However, these were based on survey reports rather than empirical studies, and the role of explanatory factors was not adequately investigated.

\section{Online Learning}

Developing an online information gaining of design or continuity of a learning interface is very much needed during a COVID-19 pandemic that has ravaged almost the entire world. Pandemic that disturbs every factor in life, particularly education. Therefore, if a pandemic occurs in the future, a well-planned lesson plan is intended to increase and enhance online learning or online courses on a large scale. 
Online learning is defined as learning which takes place in whole or in part over the Internet (Bakia et al., 2012; Means et al., 2009). Online learning suggested that student learning outcomes in classes are affected by the features of online course design (Alabbasi, 2017), to some degree, online learning studies draw on the constructivist approach to learning (noted above) that emphasizes learning experience reflection (Jonassen et al., 1993).

Inline to this statement, there has been increased interest in promoting student-centred learning among academics and policy makers. For instance, (Kearsley \& Shneiderman, 1998) noted that the basic principle behind engagement theory is that students need to be meaningfully engaged in learning activities by communication with others and worthwhile tasks. Along similar lines, (Gosling, 2003) Points out that promoting student-centred learning means imbibing a philosophy of acceptance that: 'students are individuals, each with its own learning needs; help is available to all and not stigmatized as 'remedial;'

Learning and teaching require multiple ways of interaction between the various actors. An interaction is characterized as "a mutual action or effect of two objects, two persons." In pedagogy, this topic has been studied from many points of view and has given rise to different theories, adding a new dimension to the growth of online learning (ÖZPINAR, 2020). There are three kinds of online learning, namely, synchronous, asynchronous and blended learning (Carliner, 2004; and Carliner \& Shank, 2016). Online learning can also broaden the range of courses available to students, especially for students living in rural or inner cities. There are 3 interactions that are essential in effectiveonlinecourses(Moore, 1989):(1) learner-to-learnerinteraction,(2)learner-toinstructorinteraction, and (3)learner-to-content interaction.

A teacher is regularly less talented and trained than students, especially when it comes to the use of current technology(Teeler \& Gray, 2006). Computers are usually a core tool for classroom instructional activities (Boyd et al., 2006). Technology has made a difference in improving language problems and is regarded as one of the main drivers of social and linguistic change in the digital age (Shyamlee \& Phil, 2012). Wilkinson, M. suggested Many tools, strategies and activities are accessible to Teacher candidates to start exploring language teaching technology in the classroom. They include 1) Online Tools and Smartphone Apps; 2) Mobile Applications; 3) Recording Sites; and 4) Social Networking Platforms; (Wilkinson, 2016).

It is important to note that pre-service teachers are interested and locked in the use of technology from now on, which allows multiple awesome opportunities for universities and lecturers to benefit from bringing a few technology frames into the classroom and making teaching and learning more effective(Özdemir-Baki \& Kılıçoğlu, 2020).

Inline to this statement, Tomei proposed that the top 10 innovations used as instruments to solve the evolving stock of capabilities of the 21 st century include worldwide understanding, technical skills, and problem-solving capabilities. They include social networking, smart devices and streaming video/video conferencing. Pre-Service Teachers must seize each opportunity to imbuetechnology to get ready their future at whatever point it includes to students learning outcomes(Tomei, 2016).

\section{English Language Learning}

Teaching materials play a very important role in the realities of teaching and learning languages. In the hands of Pre-Service Students, it is machines that must know not just how to use it, but also how useful it can be. Furthermore, the selection of unique teaching materials suggests an official educational option that there is an incredible qualified, political and indeed budgetary undertaking (Riazi, 2003).

Teaching materials for ELT include 'realia', representations and instructional technologies (such as overhead projectors, tape recorder, video and multimedia). They can, of course, be exploited effectively for language teaching that deals specifically with the use of visual aids (Devies, 2002). The process of teaching and learning English will be more student-centered, the quality of teaching will be improved and students' connected English skills can be viablydeveloped(Shyamlee \& Phil, 2012).

Moreover, a key component in most language program is teaching material. Richards suggested that a teacher utilizes a textbook or teaching materials by and large serve as the premise for much of language input learner gotten that happenwithin the classroom(Richards, 2001). According to (McDonough \& Shaw, 2012)The ability of all teachers to develop and analyse teaching materials is especially crucial. Tomlinson (2011b) Suggested that the production of materials today is considered both a realistic undertaking and an academic area of study. It involves the design, assessment, adaptation, and distribution of materials as a practical undertaking. As a field, it studies the nature, structure, use and assessment standards and methods of the materials (Tomlinson, 2011a).

Along similar lines, three guidelines for choosing EFL Classroom technology and resources: 1 ) Students need guidance on learning English. 2) English with many different forms, used for many different purposes. 3) The 
instructor should provide guidance by choosing the appropriate language and organizing the learning activities(Chapelle \& Jamieson, 2008).

Since students live in the digital age, demands are being made for almost all of them to become technologically trained, including pre-service teachers. Teachers may also use computer programs to create materials for students in English language teaching ( ELT), but the technology may confuse them, and the students are increasingly using computers.

\section{Research Method}

\section{Research Approach}

To address the aim of the study, the researcher used qualitative research. The research discusses the perspectives or views of students on the use of e-learning based on their analysis during the COVID-19 pandemic. Respondents are students of Education and Teacher Training Faculty at State Islamic University Banten, Indonesia.This universitywasselectedbecauseit isdiverseingeography and size(studentenrolmentnumbers are 4000 students), In this research, the researcher collected data from one hundred thirteen students ( $\mathrm{F}=18$ and M=95), as sample in English for Islamic Studies (EIS) course who were active involve in online learning activities during COVID-19 pandemic.

\section{Procedure}

The researcherdistributed an online survey to the students to complete the form and share their view on online learning during the pandemic. The questions were the context knowledge of technology from pre-service teachers, including the medium used in learning, the perspective of pre-service teachers on the teaching materials and the online method used in the classroom. The research was conducted from April 2020 to June 2020.

\section{Data Analysis}

Through this study, the researcher expected to find out the views of free-service teachers who practiced learning English for Islamic Studies (EIS) as part of his teaching processes using online learning. The qualitative results in this study used to analyze the data. The results were represented with the help of tables and different figures.

\section{The Result And Discussion}

\section{Demographic Respondents}

The first portion of the survey was designed to collect demographic characteristic of respondents and their experience with online learning. Only pre-service teachers who were taking an online course asked to participate.

The demographic profile of participant denoting gender, age and educational disciplines as presented in Table 1. Most of the students are female (84.07\%), 38.94\% are 21-22 years-old. Most participants were studying in the discipline of Islamic education $(31 \%)$, whereas others were in Islamic educational management $(26.5 \%)$, Arab education $(23.9 \%)$, Islamic early education $(11.5 \%)$, Madrasah Education (8\%) participants reported they had completed English courses from 2 to 6 credits.

Table1. Demographic profile of participants

\begin{tabular}{llll}
\hline & & $\begin{array}{l}\text { Number } \\
(\mathbf{N}-113)\end{array}$ & Percent \\
\hline Gender & Male & 18 & $15.93 \%$ \\
& Female & 95 & $84.07 \%$ \\
& $17-18$ & 27 & $23.89 \%$ \\
& $19-20$ & 40 & $35.40 \%$ \\
& $21-22$ & 44 & $38.94 \%$ \\
& Over 22 & 2 & $1.77 \%$ \\
& & & \\
& Islamic education & 35 & $31.0 \%$ \\
& Arabic education & 27 & $23.9 \%$ \\
& Islamic early education & 13 & $11.5 \%$ \\
& Madrasah education & 8 & $7.1 \%$ \\
& Islamic Educational Management & 30 & $26.5 \%$ \\
\hline
\end{tabular}




\section{The Platform used by Pre-service Teachers}

One of the initial questions was to explore the most frequently used platforms tools, as shown in Table 2 . Platforms used such as the internet browser, word processing tools, smartphone instant messages, social media sites, etc.

The finding revealed that the platforms considered the highest number used by respondents was Zoom meeting (44.25\%), followed by google meet (16.81\%) and Microsoft teams (3.54\%). It was seen that more than half of the participants was using an Android. The flatform that received the number of rating never used in PC or laptop was Zoho Meeting. The results are presented in Table 2.

Table 2: Distribution of Participants' Frequently usage of the platforms/devices.

\begin{tabular}{lllllll}
\hline Type of Platforms & $\begin{array}{l}\text { PC/ } \\
\text { Laptop }\end{array}$ & $\mathbf{( \% )}$ & $\begin{array}{l}\text { Mobile/ } \\
\text { Tablet }\end{array}$ & $\mathbf{( \% )}$ & Android & $\mathbf{( \% )}$ \\
\hline Zoom Meetings. & 12 & 10.62 & 2 & 1.76 & 50 & 44.25 \\
Google Meet. & 6 & 5.31 & 1 & 0.88 & 19 & 16.81 \\
Microsoft Teams. & 4 & 3.54 & 0 & 0 & 0 & 0.00 \\
GoToMeeting & 2 & 1.77 & 2 & 1.76 & 6 & 5.31 \\
FreeConference & 3 & 2.65 & 1 & 0.88 & 3 & 2.65 \\
Zoho Meeting & 0 & 0 & 0 & 0 & 1 & 0.88 \\
Cisco Webex & 1 & 0.88 & 0 & 0 & 0 & 0.00 \\
\hline
\end{tabular}

Pre-service teachers' perception online learning

Responses to the question on the pre-service teachers perceive online learning suggested that 81 respondents used course content $(71.68 \%), 3$ persons were not valued. It was component online considered by the highest number of respondents to be very valuable. Overall, the results show that the components that received valuable used by respondents was discussion, 63 respondents $(55.75 \%)$, this was followed by announcement $(53.10 \%)$, assignment $(45.13 \%)$, and mail $(42.44 \%)$ on a daily basis.

The component that received the highest number of ratings from respondents for never being used was the chat component $(31.86 \%)$, followed web link (15.4\%) and calendar $(11.50 \%)$. The results are presented graphically in figure 1.

The result of this study was in line with the previousresearch that watchedan evaluation of students' perception and engagement with online learning (Ituma, 2011). It was found that a large percentage of students had very positive perceptions of usage of online learning.

Figure 1 Pre-service teachers' report of usability of online components

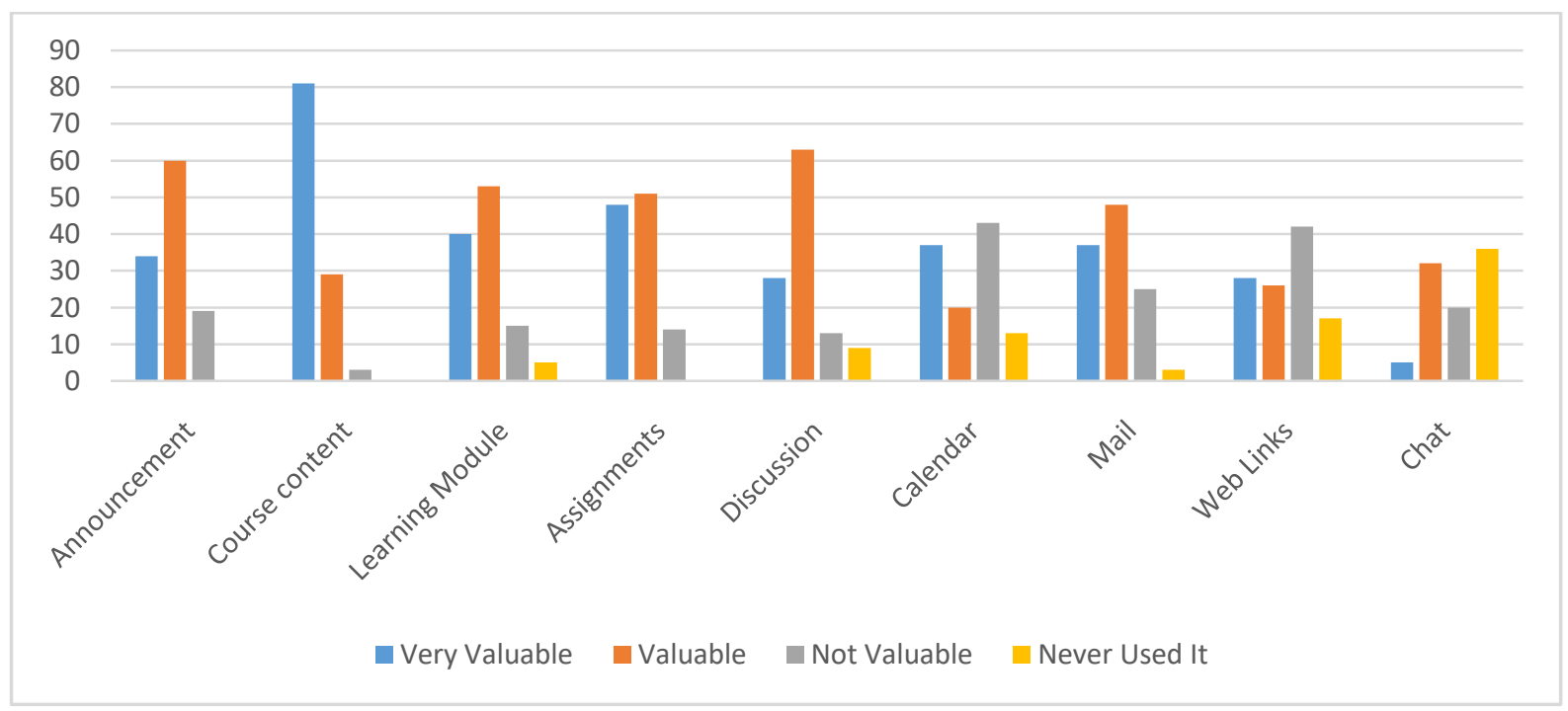


Table 4 is analysis of usage of online meeting tools in COVID-19 pandemic situation. It is known that the respondents screen sharing $(41.6 \%)$ used intensively, followed by meeting with audio (17.7\%), video broadcasting (13.3\%), and audio streaming (4.4\%) for presentation and sharing the materials.

Table 4. Usage of Online Meeting Tools for Education

\begin{tabular}{|c|c|c|c|c|c|c|}
\hline $\begin{array}{l}\text { Usage online } \\
\text { meeting tools }\end{array}$ & $\begin{array}{l}\mathrm{PC} / \\
\text { Laptop }\end{array}$ & $(\%)$ & $\begin{array}{l}\text { Mobile/ } \\
\text { Tablet }\end{array}$ & $(\%)$ & Android & $(\%)$ \\
\hline Video Broadcasting & 5 & 4.4 & 2 & 1.8 & 15 & 13.3 \\
\hline Screen sharing & 7 & 6.2 & 1 & 0.9 & 47 & 41.6 \\
\hline Audio streaming & 5 & 4.4 & 0 & 0 & 5 & 4.4 \\
\hline Meeting with audio & 6 & 5.3 & 0 & 0 & 20 & 17.7 \\
\hline
\end{tabular}

At the end of the study, the pre-service teachers were asked to complete the survey adapted from Martin and Bolliger to assess their perception of using online learning (Martin \& Bolliger, 2018). Pre-service teachers indicate their extent of agreement with 12 statement on a 5-level Likert scale (strongly agree, agree, neutral, disagree and strongly disagree). The question and the results are depicted in Table 4.

Analysis of the perception of pre-service teachers of doing online learning shown that 'engage in ongoing professional development and networking activities' was the highest number of respondents to be 'strongly agree,' followed by 'use online learning tools to enhance teaching and learning.'

Table 4. Participants Perception Summary

\begin{tabular}{|c|c|c|c|c|c|c|c|c|c|c|c|}
\hline \multirow{2}{*}{$\begin{array}{l}\text { Questions: Doing } \quad \text { Online } \\
\text { Learning }\end{array}$} & \multirow{2}{*}{$\begin{array}{l}\text { Mean } \\
\text { score }\end{array}$} & \multicolumn{2}{|l|}{ SA } & \multicolumn{2}{|l|}{$\mathrm{A}$} & \multicolumn{2}{|l|}{$\mathrm{N}$} & \multicolumn{2}{|l|}{ D } & \multicolumn{2}{|l|}{ SD } \\
\hline & & No. & $\%$ & No. & $\%$ & No. & $\%$ & No. & $\%$ & No. & $\%$ \\
\hline $\begin{array}{l}\text { 1. Improve my understanding of } \\
\text { online and share common } \\
\text { interests. }\end{array}$ & 4.218 & 46 & 41 & 41 & 36.2 & 24 & 21.2 & 2 & 1.8 & 0 & 0 \\
\hline $\begin{array}{l}\text { 2. Help me to support the } \\
\text { development of the knowledge, } \\
\text { skills, and attitudes }\end{array}$ & 4.087 & 36 & 32 & 59 & 52 & 18 & 16 & 0 & 0 & 0 & 0 \\
\hline $\begin{array}{l}\text { 3. Incorporate me the pedagogical } \\
\text { approaches }\end{array}$ & 4.256 & 25 & 22.1 & 48 & 42.4 & 34 & 30.1 & 2 & 1.8 & 4 & 3.6 \\
\hline $\begin{array}{l}\text { 4. Use online learning tools to } \\
\text { enhance teaching and learning. }\end{array}$ & 4.343 & 51 & 45.1 & 40 & 35.4 & 22 & 19.5 & 0 & 0 & 0 & 0 \\
\hline $\begin{array}{l}\text { 5. Assisted me in preparing topic } \\
\text { and present my findings in a } \\
\text { delivery method of my choice. }\end{array}$ & 4.222 & 30 & 26.5 & 50 & 44.2 & 29 & 25.7 & 2 & 1.8 & 2 & 1.8 \\
\hline $\begin{array}{l}\text { 6. Use appropriate technology } \\
\text { tools for assessment. }\end{array}$ & 4.142 & 16 & 14.2 & 77 & 68.1 & 20 & 17.7 & 0 & 0 & 0 & 0 \\
\hline $\begin{array}{l}\text { 7. Interact with peers through } \\
\text { student presentations }\end{array}$ & 4.333 & 16 & 14.2 & 75 & 66.3 & 22 & 19.5 & 0 & 0 & 0 & 0 \\
\hline $\begin{array}{l}\text { 8. Use technology to connect } \\
\text { globally with a variety of regions } \\
\text { and cultures. }\end{array}$ & 4.157 & 20 & 17.7 & 54 & 47.8 & 34 & 30.1 & 5 & 4.4 & 0 & 0 \\
\hline $\begin{array}{l}\text { 9. Address the legal, ethical, and } \\
\text { socially responsible use of } \\
\text { technology in education. }\end{array}$ & 4.06 & 48 & 42.4 & 40 & 35.4 & 25 & 22.2 & 0 & 0 & 0 & 0 \\
\hline $\begin{array}{l}10 . \text { Engage in ongoing } \\
\text { professional development and } \\
\text { networking activities. }\end{array}$ & 4.458 & 67 & 59.2 & 36 & 32 & 10 & 8.8 & 0 & 0 & 0 & 0 \\
\hline $\begin{array}{l}\text { 11. Interact with content in more } \\
\text { than one format }\end{array}$ & 4.208 & 40 & 35.3 & 34 & 30.1 & 34 & 30.1 & 2 & 1.8 & 3 & 2.7 \\
\hline $\begin{array}{l}\text { 12. Use self-tests to check their } \\
\text { understanding of materials. }\end{array}$ & 4.287 & 25 & 22.2 & 48 & 42.4 & 32 & 28.3 & 5 & 4.4 & 3 & 2.7 \\
\hline
\end{tabular}




\section{Learning Environment}

When asked via virtual "what kind of learning environment (Synchronous, Asynchronous, blended online) is the strongest and usage of online meeting tool most significant learning?" a total 54 (48\%) of 113 participants mentioned that blended learning is significant learning as shown in figure 2.

Figure 2. Pre-service teaches self-report of type of online learning

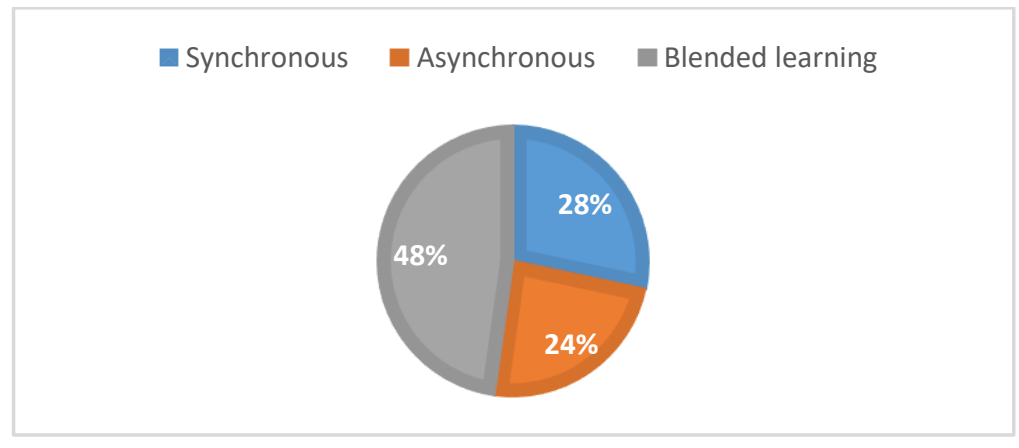

Then, figure 2 indicates that $24 \%$ of participants choose asynchronous learning. It is not denied that limited facilities in accessing the network online learning during Covid-19 pandemic. In addition to the survey, the qualitative finding revealed that there were three common reasons for Pre-Service' unwilling to use technology in designing teaching materials. 1) lack of supervision time; 2) lack of Pre-Service teachers' knowledge on the student's field; and 3) confusing in selecting platform tools for students regarding their level of knowledge.

The following quotes from participants' answer from the survey, for example, one participant comment, "the role of the lecturer as a model is very important." Regarding synchronous sessions, one student wrote, "I prefer to think over deeper the concept before responding. I feel synchronous session more interactive." Using technologyisafundamentalpartofthe dailylifeofstudents, the following one participant offered a perspective on the use of chatting, 'Technology-related threats occur, in particular negative effects on Islamic traditions, dangers of sexual harassment and illegal content', the person wrote, "pre-service teachers need to look at a few points of view that can help them expand their English-language knowledge and skills to be a professional educator".

\section{Conclusion}

To reach successful and effective results with technology in learning, the pre-service teachers have increased the confidence and professional competence. Utilizingtechnology is altogether more critical to engage pre-service teachers in advancingprofessionaldevelopment. Pre-Service Teachers have numerousconceivable ways to learn with technology. The result of the study shows that asynchronous operations can be more sensible than synchronous ones. Flexibility with task deadlines should be considered inside classes, training programs and institutional policies.

It can be concluded that using online is nowadays inevitable in the classroom. When used appropriately online learning is quite beneficial for learners and teachers if they are considered only as mere entertainment, but carefully the platform's tool can be useful for both practising productive skills and receptive skills.

COVID-19 pandemic has forced universities to understand the importance of online training for pre-service teachers. The experience of students with online learning was comparable with those of previous research. In addition to acquiring information, the present study revealed the effect of online learning on our students' morale by providing a distraction from the current pandemic situation. It can be inferred that online teaching is feasible, cheap and needs to be a part of Indonesia's undergraduate training outside the current lockdown. Supports from institution and government are needed for the success of online learning.

This study has been limited to only the perspective of pre-service teachers in the State Islamic University of Banten. Future research may investigate gender differences in designing online materials and social media through an interview or survey questionnaire. 


\section{Acknowledgment}

The researcher gratefully acknowledges the participant support for this study is from theFaculty at The State Islamic University Banten, Indonesia, who contributed to this research during COVID-19 pandemic

\section{References}

Abere, O. (2020). Survival Analysis of Novel Coronavirus ( 2019-nCov ) Using Nelson Aalen Survival Estimate . International Journal of Finance, Accounting and Corporation, 1(1), 17-24.

Adit, A. (2020, March). 12 Aplikasi Pembelajaran Daring Kerjasama Kemendikbud, Gratis! Kompas.Com. https://edukasi.kompas.com/read/2020/03/22/123204571/12-aplikasi-pembelajaran-daring-kerjasamakemendikbud-gratis?page $=$ all.

Alabbasi, D. (2017). Exploring Graduate Students' Perspectives towards Using Gamification Techniques in Online Learning. Turkish Online Journal of Distance Education, 18(3), n3.

Alqurashi, E. (2019). Predicting student satisfaction and perceived learning within online learning environments. Distance Education, 40(1), 133-148. https://doi.org/10.1080/01587919.2018.1553562

Bakia, M., Shear, L., Toyama, Y., \& Lasseter, A. (2012). Understanding the Implications of Online Learning for Educational Productivity. Office of Educational Technology, US Department of Education.

Boyd, D., Grossman, P., Lankford, H., Loeb, S., \& Wyckoff, J. (2006). How changes in entry requirements alter the teacher workforce and affect student achievement. MIT Press.

Carliner, S. (2004). An overview of online learning (Second). Human Resource Development Press Inc.

Carliner, S., \& Shank, P. (2016). The e-learning handbook: past promises, present challenges. John Wiley \& Sons.

Chapelle, C., \& Jamieson, J. (2008). Tips for teaching with CALL: Practical approaches to computer-assisted language learning. Pearson Education.

Demuyakor, J. (2020). Coronavirus (COVID-19) and Online Learning in Higher Institutions of Education: A Survey of the Perceptions of Ghanaian International Students in China. Online Journal of Communication and Media Technologies, 10(3), e202018. https://doi.org/10.29333/ojcmt/8286

Devies, A. and M. K. (2002). Materials evaluation and design for language teaching. Edinburgh University Press. Djuanda, U., Barat, J., Aliyyah, R. R., Djuanda, U., Barat, J., Rachmadtullah, R., Timur, J., Samsudin, A., Indonesia, U. P., Barat, J., Syaodih, E., Indonesia, U. P., Barat, J., Nurtanto, M., Sultan, U., Tirtayasa, A., Riana, A., Tambunan, S., \& Medan, U. N. (2020). The Perceptions of Primary School Teachers of Online Learning during the COVID-19 Pandemic Period: A Case Study in Indonesia. 7(2), 90-109.

Dudeney, G. and Hockly, N. (2008). How to Teach English with Technology. London: Longman.

Fithra, H. (2020). Covid-19 and Online Learning. Mediaindonesia. https://doi.org/https://mediaindonesia.com/read/detail/298964-covid-19-dan-pembelajaran-daring

Gosling, D. (2003). Supporting student learning. A Handbook for Teaching and Learning in Higher Education, 113.

Gross, M. (2020). Virus outbreak crosses boundaries. Current Biology, 30(5), R191-R194. https://doi.org/10.1016/j.cub.2020.02.049

He, K., Stolarski, A., Whang, E., \& Kristo, G. (2020). Addressing General Surgery Residents' Concerns in the Early Phase of the COVID-19 Pandemic. Journal of Surgical Education. https://doi.org/10.1016/j.jsurg.2020.04.003

Ituma, A. (2011). An evaluation of students' perceptions and engagement with e-learning components in a campus based university. Active Learning in Higher Education, 12(1), 57-68. https://doi.org/10.1177/1469787410387722

Jonassen, D., Mayes, T., \& McAleese, R. (1993). A manifesto for a constructivist approach to uses of technology in higher education. In Designing environments for constructive learning (pp. 231-247). Springer.

Kearsley, G., \& Shneiderman, B. (1998). Engagement theory: A framework for technology-based teaching and learning. Educational Technology, 38(5), 20-23.

Mardiah, H. (2020). The Use of E-Learning to Teach English in the Time of the Covid-19 Pandemic. 1(2), 4955.

Martin, F., \& Bolliger, D. U. (2018). Engagement matters: Student perceptions on the importance of engagement strategies in the online learning environment. Online Learning Journal, 22(1), $205-222$. https://doi.org/10.24059/olj.v22i1.1092

McDonough, J., \& Shaw, C. (2012). Materials and Methods in ELT. John Wiley \& Sons.

Means, B., Toyama, Y., Murphy, R., Bakia, M., \& Jones, K. (2009). Evaluation of Evidence-Based Practices in Online Learning. Structure, 66.

Moore, M. G. (1989). Three types of interaction. American Journal of Distance Education. https://doi.org/https://doi.org/10.1080/08923648909526659

Morrison, G. R., Ross, S. M., Kalman, H. K., \& Kemp, J. E. (2013). Designing effective instruction (7e édition). Hoboken. New Jersey: Wiley. 
Murphy, M. P. A. (2020). COVID-19 and emergency eLearning: Consequences of the securitization of higher education for post-pandemic pedagogy. Contemporary Security Policy, 41(3), $492-505$. https://doi.org/10.1080/13523260.2020.1761749

Özdemir-Baki, G., \& Kılıçoğlu, E. (2020). Examination of teachers' classroom practices through a video club process in terms of students' mathematical thinking. Turkish Journal of Computer and Mathematics Education.

ÖZPINAR, İ. (2020). Preservice Teachers' Use of Web 2.0 Tools and Perspectives on their Use in Real Classroom Environments. Türk Bilgisayar ve Matematik Eğitimi Dergisi, 11(3), 814-841.

Riazi, A. M. (2003). What do textbook evaluation schemes tell us?: A study of the textbook evaluation schemes of three decades. In Methodology and materials design in language teaching: Current perceptions and practices and their implications (pp. 52-69). SEAMEO Regional Language Centre.

Richards, J. C. (2001). Curriculum development in Language Teaching. Cambridge University Press.

Sharma, U., Forlin, C., Deppeler, J. \& Guang-xue, Y. (2013). Reforming teacher education for inclusion in developing. Journal of Inclusive Education, 1(1), 3-16.

Shyamlee, S. D., \& Phil, M. (2012). Use of technology in English language teaching and learning: An analysis. International Conference on Language, Medias and Culture, 33(1), 150-156.

Simamora, R. M. (2020). The Challenges of Online Learning during the COVID-19 Pandemic: An Essay Analysis of Performing Arts Education Students. Studies in Learning and Teaching, 1(2), 86-103. https://doi.org/https://doi.org/10.46627/silet.v1i2.38

Teeler, D., \& Gray, P. (2006). How to Use the Internet in ELT. Pearson Education India.

The Jakarta Post. (2020). Nadiem's campus reforms have yet to address student exploitation during internships. https://www.thejakartapost.com/news/2020/02/12/nadiem-s-campus-reforms-have-yet-address-studentexploitation-during-internships.htm

Tomei, L. (2016). Exploring the new era of technology-infused education. IGI Global.

Tomlinson, B. (2011a). Materials development in language teaching. Cambridge University Press.

Tomlinson, B. (2011b). Principles and procedures for self-access materials. Reading.

UNESCO. (2020). 290 million students out of school due to COVID-19. https://en.unesco.org/news/290-millionstudents-out-school-due-covid-19-unesco-releases-first-global-numbers-and-mobilizes

W.H.O. (2020). Coronavirus disease (COVID-19) pandemic. https://www.who.int/emergencies/diseases/novelcoronavirus-2019?gclid=EAIaIQobChMIspa91snl6wIVgnwrCh0PXQfQEAAYASAAEgKt6PD_BwE

Whisenand, T. G., Grove, J. L., \& Dunphy, S. M. (2006). Accelerating Student Learning of Technology Terms : The Crossword Puzzle Exercise. Journal of Information Systems Education, 21(2), 141-149.

Wilkinson, M. (2016). Language learning with ICT. In English Language Teaching Today (pp. 257-276). Springer.

Yang, Y., Peng, F., Wang, R., Guan, K., Jiang, T., Xu, G., Sun, J., \& Chang, C. (2020). The deadly coronaviruses: The 2003 SARS pandemic and the 2020 novel coronavirus epidemic in China. Journal of Autoimmunity, 102434.

Yulia, H. (2020). Online Learning to Prevent the Spread of Pandemic Corona Virus in Indonesia. ETERNAL (English Teaching Journal), 11(1) 